ing apparatus, etc., for deep sea work. Unfortunately, the methods of work preclude the use of preserved material, as this subject can only be prosecuted by means of culture work. Not only would such a department of research upon our scientific exploring expeditions add greatly to our knowledge of bacterial life, but the lower forms of fungi could be investigated as well.

University of Chicago.

\title{
A peculiar case of plant dissemination.
}

\section{EDWARD L. BERTHOUD.}

Studying lately with intense interest “Island Life," by Alfred Russell Wallace, and his remarks upon the dissemination of plant life everywhere, both on continents and islands, it brought to my mind what many years ago I had observed during a long residence, and numberless scouts, excursions, surveys and pleasure trips I have made in the region included between the Missouri river and Great Salt Lake, and from the $342_{2}^{\circ} \mathrm{N}$. latitude to that of Eau qui Court in Dakota, and Sun river in Montana.

As these may be of interest and some value in the determinations of geographical botany, and have a bearing in the elucidation of geological botany, I will briefly give the more salient points of these observations. I can show to some extent that between the Missouri river and the Rocky mountains, the American buffalo has been an efficient agent in plant dissemination. Until within twenty-six years the buffalo was known to range from Peace river and Athabaska valley to central Texas. Very much as our Indian tribes are known to do, the buffalo uniformly followed trails in their annual migrations from north to south, or vice versa, very rarely deviating from them, whether across prairie or woods, or over spurs of the Rocky mountain range, on their migrations through South, Middle, North Park and Laramie Plains. And when in the spring the former countless herds from Texas moved north across the Arkansas, Smoky Hill, Republican and Platte rivers, the same trails were used, the same river fords crossed, and, following the best ground for their migrations, their sagacity or instinct (if you choose so to call their

Vol, XVII.-No. Io. 
inherited faculty) made them follow trails over the lowest and best divides between streams.

When following large herds in Nebraska, Kansas, Colorado, Indian Nation and Texas, we have seen these trails in soft rich ground worn down five or six feet deep, thirty or forty feet wide, as well defined as a graded wagon road.

We have spoken of their migration only in a sense restricted to our personal knowledge in the region we have already described. Yet from the best information we can get we find that this same yearly change of locality occurred in northern Idaho, Montana and Dakota, and north of the Black Hills, not so much from scarcity of forage, as the necessity of shelter from the winter snows and blizzards of the upper Missouri and Yellowstone prairies; while in British America, according to the accounts of Franklin, Richardson, and also Messrs. Milton and Cheadle for the Saskatchewan and upper Athabaska valleys, the buffalo were driven by snow and intense cold from the open country into the timbered valleys, and forests west of the open plains and in the Athabaska region.

In the spring the general movement of the buffalo was north into Nebraska, Colorado, Wyoming and Kansas across the Arkansas river, then north to lat. $44^{\circ}$ or even farther, and largely governed by the more or less abundance of grass and water, but as early as May vast herds were already in the Platte valley, invading the vast prairies of Dakota and Nebraska. In the fall the returning herds would be seen in October in the Platte valley, or even as far as the Arkansas.

These points explained and shown, we will now explain in what manner this bears on the question of the dissemination and intermingling of plant life within the limits given in this discussion.

The American buffalo, a good deal as their congeners in the eastern hemisphere, delight in rolling and plowing up with their horns the soft, muddy soil of the prairies, or of any bluff bank; rolling around they formed countless numbers of shallow depressions, circular in shape, very often retaining rain water for days, which were familiarly known as "buffalo wallows."

So that along deep, wide trails, and in the wallows, the sod being worn away, and the soil loosened and trampled up, large areas would be conspicuous by nourishing and perpetuating a new growth of plant life, introduced, generally or altogether foreign to a prairie country, and of such species as found these conditions favoring their growth. 
We would find there Plantago (2 species), Asclepias Syriaca, Trifolium, Thlaspi, Amarantus, Chenopodium album, Martynia proboscidea, Sinapis, Portulaca, Lippia cuneifolia, and the grasses, such as Cenchrus, Stipa, Setaria, Elymus, Dactylis, Deschampsia, Panicum Crus-galli, Euphorbia, Glycyrrhiza, Epilobium.

We could add to this list Helianthus, but as this plant is firmly established as a native to the soil of this whole region. and universally appears along old roads and in all the valleys, its dissemination seems to be largely independent of artificial dissemination, and dependent for its spread solely on the bared condition of the ground when sodless. We have so far given what annuals or biennials are found in the artificial denudations made by the buffalo. To these we can add Rhus glabra, and a plum called "sand plum," a low spreading bush, two feet or less in height, abundant south of the Arkansas and in the Indian Nation. It was found by me near old buffalo trails in north Colorado, up to near North Platte in Wyoming. The same can be said of Rhus glabra, which in Colorado, at the foot of our Rocky Mountains, has been introduced since I 860; and found in Wyoming as far north as the forty-second parallel: the plum might be, perhaps, the Prunnus pumila, but may be only a variety of P. Chicasa, though I can hardly admit this as probable.

Now how do the buffalo distribute all these plants and shrubs, which so fix themselves in the places artificially formed in this whole vast region? An inspection of the enormous pad of hair four to twelve inches long that clothes the whole front of the buffalo's head from the root of the horns nearly to the muzzle, besides the dense long hair that clothes the legs and breast of the animal, reveals masses of hair, matted with mud, seeds, twigs cactus fronds and roots.

When examining the heads of dead buffalo I repeatedly noticed, matted in the long hair of the forehead, the woody two-tined capsules of Martynia with the seeds of the plant; also seeds of Bidens, Glycyrrhiza, Stipa, Setaria, Elymus, the seeds and pappus of Helianthus and other unknown Compositæ, hispid twigs of Euphorbia, and seeds of some species of Rhus, perhaps R. trilobata very common in Colorado, seeds of Obione canescens, and seeds either of Amarantus or Chenopodium. The pad altogether made up an ambulant Wardian
case. 
Now such a pad of hair (overlooking the breast and legs of the animal) matted as we have said, and daily rubbed in earth banks or wallows, is as good an apparatus for artificial dissemination as could be imagined when we consider the range and habits of the animal. Given a herd of ten thousand buffaloes roving from the Red River of Texas to northern Nebraska and Montana, we can justly imagine that the seeds of southern species of plant and shrub life would in time be left at intermediate points most favorable to their growth, while the returning herds in the fall and winter would be laden in the same manner with northern plant seeds to be in their turn tropped or left many miles south of their former habitat. Nor $\mathrm{s}$ it necessary that any one species of the plants should be conceived as forcibly carried from Texas to Montana by one migration; on the contrary taking the case of Martynia, a seed brought from Red river is dropped in a favorable spot on the Arkansas in some trail or wallow. There it matures seeds mayhap for years; some of them are again entangled in the forehead or the front woolly hairs of a buffalo on its neck or fore legs and are finally dropped by chance on the Smoky Hill or Republican The same actions may recur, and the plant seeds be carried into the next valley or to the next prairie divide, so that in course of time it is not at all improbable that any one species of plant would finally reach the uttermost northern limit of the buffalo's northern range, the plant being, as it were, slowly acclimated by the successive transference from age to age in its continued dissemination. What we argue in relation to the Martynia, can equally apply to any plant or shrub seed, varying in its northward or southward progression just in proportion to its adaptability to withstand heat or cold, drouth or moisture, and its adaptation to extraneous transportation.

Now, if we turn to Richardson's Appendix to his Arctic expedition we find that he gathered Opuntia glomerata at the Lake of the Woods, while others have found it since near Lake Winnipeg. The occurrence of such a southern type of plant about latitude $50^{\circ}$ to $5 \mathrm{I}^{\circ}$ north, we believe was largely due to a progressive dissemination by the buffalo, not only by seed, but also by direct conveyance of fronds and roots. This transfer we conceive highly probable, as well as that of many other plants and shrubs that range into British America from as far south as latitude $35^{\circ}$ and $36^{\circ}$. We are certain 
the sand plum has advanced from the Arkansas river into northern Colorado and Wyoming, since in the scope of the buffalo country extending from the forks of Platte river to the Rocky Mountains, I have found it only where the main buffalo trails formerly existed. Rhus glabra is, however, such a cosmopolitan shrub, that its dissemination north may be as justly ascribed to recent settlement as to the artificial dissemination we have advocated.

Again, if the fossil sequoias, figs, magnolias, oaks, palms, liquidambars, cycads, salisburias, laurels, persimmons, cinnamonums, aralias, sassafras and many other semi-tropical or south temperate trees and shrubs now found in the Cretaceous, Eocene and Miocene beds of Colorado, were derived from the Arctic regions originally; and if their modified descendants now found extant from the Missouri river south to the Mexican gulf are their living representatives, then it is quite remarkable that no representatives of the cactus family occur either in Greenland strata or in the same formations in Colorado. Their total absence also from the Pliocene strata of South Park, so rich in Sequoia, Glyptostrobus, Myrica, Rhus, Sapindus, Ficus, Planera, Cesalpinus, Acacia, Zizyphus, Ilex, etc., though really only negative evidence of their non-existence there, is strongly corroborated by the fact that the Opuntia is a plant that avoids damp, densely timbered surfaces. It delights in dry, stony, sandy soils, and requires but little water the whole year round. The vegetation of the Cretaceous, Miocene, Eocene and Pliocene strata in Colorado predicates the presence of rich, damp soils, either of valleys or low humid plains. Although the presence of fossil cacti has never yet been proven in any of the formations we are now considering, the fleshy nature of the fronds of Opuntia would naturally be very unfavorable to fossilization; but its abundant seeds of a very hard consistence, would be unusually well fitted for preservation, for we find to-day in the strata under consideration fossil nuts of Fagus, Corylus, Carya, Diospyros and a species of plum, besides palm nuts, fern fronds with sporangia complete, seeds of grasses and carices, also of elm and Planera.

The reader may ask what has all this to do with the question of "buffalo pads." The answer is simple enough. We think we prove very strongly by this that the cacti that extend from southern latitudes to Lake Winnipeg, are colonies that in the 
course of ages have been gradually acclimated by artificial dissemination, and not the fragments of a flora derived from Arctic regions. Granting this, then the same method would apply to Clematis Virginiana, Negundo aceroides, Ampelopsis quinquefolia, Prunus (Cerasus) serotina, Cornus, Shepherdia argentea, Sambucus pubens, Hypopitys; all found according to Richardson far north in the British possessions, within the old buffalo range, but also common as far south as latitude $35^{\circ}$ north.

Golden, Colorado.

\section{Notes on certain species of Erythronium.}

E. B. KNERR.

Perhaps there is no more interesting genus of plants among Liliaceæ than Erythronium. The species are the first of the order to appear in the spring and in point of beauty are second to none. Besides, there are features of propagation quite as puzzling and wonderful as any to be found.

Of the three species to be mentioned E. Americanum Ker. is the most common in the eastern states, E. albidum Nutt. in the central and western states to Kansas and Nebraska, while E. mesochoreum Knerr belongs to the states of the lower Missouri valley. All three species present two kinds of plants: a flowering two-leaved and a flowerless one-leaved form, both of which arise from underground corms. In the flowering forms these corms, or rather fleshy bulbs, consist of a series of corms arranged somewhat spirally one within the other, sometimes as many as four or five in number, the youngest innermost, each corm producing its plant in succession a year apart and beginning with the oldest and outermost. Sometimes, however, in E. mesochoreum and E. Americanum it happens that two and even three of these corms may develop at once, producing as many leafy scapes apparently from the same root, when ordinarily but one would be expected. As yet I have never noticed this in E. albidum.

The sterile forms (one-leaved) both of E. Americanum and E. albidum, and sometimes the flowering, send out underground off-shoots or rhizomes which produce at their extremities new corms destined to furnish the plants of the next season. In the two species, however, there is this difference: 


\section{$2 \mathrm{BHL}$ Biodiversity Heritage Library}

Berthoud, Edward L. 1892. "A Peculiar Case of Plant Dissemination." Botanical gazette 17(10), 321-326. https://doi.org/10.1086/326848.

View This Item Online: $\underline{\text { https://www.biodiversitylibrary.org/item/92733 }}$

DOI: https://doi.org/10.1086/326848

Permalink: https://www.biodiversitylibrary.org/partpdf/222189

\section{Holding Institution}

Missouri Botanical Garden, Peter H. Raven Library

\section{Sponsored by}

Missouri Botanical Garden

\section{Copyright \& Reuse}

Copyright Status: Public domain. The BHL considers that this work is no longer under copyright protection.

This document was created from content at the Biodiversity Heritage Library, the world's largest open access digital library for biodiversity literature and archives. Visit BHL at https://www.biodiversitylibrary.org. 